\title{
Simultaneous Abdominoplasty and Umbilical Hernia Repair via Laparoscopy: a Preliminary Report
}

\author{
Hristo D. Shipkov ${ }^{1,2}$, Ali Mojallal ${ }^{1}$, Fabienne Braye ${ }^{1}$ \\ ${ }^{1}$ Department of Plastic, Reconstructive and Aesthetic Surgery, Croix Rousse Hospital, Lyon, France \\ 2 Department of Plastic and Craniofacial Surgery, St. George University Hospital, Plovdiv, Bulgaria
}

\section{Correspondence: \\ Hristo D. Shipkov, Department of Plastic, Reconstructive and Aesthet- ic Surgery, Croix Rousse Hospital, 103 Grande rue de la Croix Rousse Lyon, France \\ E-mail:cshipkov@hotmail.com Tel: 0033426732822 \\ Received: 05 Oct 2015 \\ Accepted: 16 Nov 2016 \\ Published Online: 06 March 2017 \\ Published: 27 June 2017}

Key words: abdominoplasty, umbilical hernia, laparoscopic repair

Citation: Shipkov HD, Mojallal A, Braye F. Simultaneous abdominoplasty and umbilical hernia repair via laparoscopy: a preliminary report.

Folia Medica 2017;59(2):222-227. doi: 10.1515/folmed-2017-0026
Background: Umbilical hernias (UH) are common in postpartum patients seeking abdominal contouring surgery and the question of simultaneous abdominoplasty and UH repair is raised. This presents, however, a risk to the umbilicus vascularisation with possible umbilical necrosis. To minimize this risk we associated abdominoplasty with laparoscopic UH repair. The aim of this study was to present the technique of simultaneous abdominoplasty and $\mathrm{UH}$ repair and the first results.

Materials and methods: Simultaneous abdominoplasty and laparoscopic mesh $\mathrm{UH}$ repair was analysed in the first 10 cases. The intervention was performed by a plastic surgeon and a general surgeon. It begins as a standard abdominoplasty with flap elevation, umbilicus detachment and diastasis repair, if indicated. The second stage is the UH repair via laparoscopy using an intraperitoneal mesh. The third stage consists of umbilical transposition and closure of the abdominoplasty incision.

Results: We had no complications at the umbilicus or the hernia mesh. In all cases, umbilical vascularisation was preserved and no hernia recurrence was noted.

Conclusions: Our first results suggest that the simultaneous UH repair with abdominoplasty is safe, minimizing the risk to the umbilicus blood supply. These first results encourage us to recommend this approach and perform a more detailed analysis of the whole series since our first case.

\section{BACKGROUND}

Umbilical and epigastric hernias are primary midline defects that are present in up to $50 \%$ of the population. In a recent study, only about $1 \%$ of the population was found to have this specific diagnosis, and only about $11 \%$ of these were repaired. ${ }^{1}$ Furthermore, umbilical hernias left without treatment may have a high social-economic impact. ${ }^{2}$

Umbilical hernias (UH) are common, especially in the postpartum patient seeking abdominal contouring surgery. Not infrequently, they are associated with diastasis of the rectus abdominis (RA) muscles. ${ }^{3}$ In such cases there is the possibility of performing simultaneously abdominoplasty and $\mathrm{UH}$ repair.

While repair of the RA muscles diastasis is a part of the abdominoplasty procedure, the UH repair can be a challenge if performed at the same time. The umbilicus has a dual blood supply - from its base and from the skin. When dissecting the abdominal flap in a classic abdominoplasty, the umbilicus stalk is detached from the skin flap. Thus, its vascularisation is provided only by the vessels entering the base of the umbilicus from the musculoaponeurotic layer. At the same time, the UH repair via direct closure or mesh requires incision at the umbilical stalk base. Any incision and dissection of $\mathrm{UH}$ at the fascial level can damage the umbilical perforating vessels resulting in necrosis and loss of the umbilicus. ${ }^{4}$ The possible consequences might be partial or full umbilical necrosis with possible infection of the prosthesis. In order to minimize the risk of potential devascularisation of the umbilical stalk we have associated the abdominoplasty (with or without diastasis repair) with UH repair via laparoscopy. Thus, any incision near the umbilicus stalk base is obviated.

The aim of this paper was to present this technique and report the first preliminary results. 


\section{MATERIALS AND METHODS}

This retrospective series comprises the first 10 cases operated on since 2010 and it covers a period of 4 years. All patients had a physical examination and ultrasound confirmation of the $\mathrm{UH}$ and diastasis. Inclusion criteria were: patients presenting rectus abdominis diastasis and umbilical hernia. Exclusion criteria were: patients presenting other type of hernias, patients with previous laparotomies. Patients' files were examined for post-operative complications and outcomes. Post-operative visits were on days 14, 30, months 3, 6 and 1 year. Herein, we present the surgical approach and technique.

Markings are made in upright and sitting positions. Surgery is performed under general anesthesia in 3 stages. The plastic surgeon performs the abdominoplasty and diastasis repair and a general surgeon performs the laparoscopic hernia repair.

\section{Stage I}

It consists of elevating the abdominal flap and the diastasis repair, if indicated. Super wet liposuction of the flanks and abdomen is performed, as indicated. After liposuction a low horizontal incision is performed. The abdominal flap is developed in the fascia superficialis plane at a mid distance between the incision and umbilicus. Then, dissection is carried out over the muscle aponeurosis. The abdominoplasty proceeds by freeing the umbilicus from the skin flap. The abdominal flap is then undermined in the midline (as an inverted $\mathrm{V}$ tunnel), preserving the lateral intercostal blood supply. This tunnel reaches the xiphoid in cases of rectus muscles diastasis. The diastasis is repaired by approaching the anterior rectus sheet by horizontal mattress sutures of Polyglycolic acid 1 (Vycril, Johnson and Johnson, USA) from xiphoid to pubis paying attention not to place any transfixiant sutures. Thus, stage $I$ is completed.

\section{Stage II}

The UH repair is performed by a general surgeon via laparoscopy. The first port is inserted via open approach under visual control. A pneumoperitone$\mathrm{um}$ is achieved via insuflation of $\mathrm{CO}_{2}$. Then under visual control of the camera 2, more $5-\mathrm{mm}$ ports are inserted in a triangle fashion in relation to the umbilicus. The camera is situated on the left or right side depending on the surgeon preferences. The hernia opening is approached and the hernia sac contents is pulled back in the abdomen. Frequently, the sac is free of contents or contains omentum majus. The peritoneal sac is then resected by electrocoagulation. An intraperitoneal prosthesis (Parietex, Covidien, USA) with corresponding dimensions is inserted in the abdominal cavity. The mesh is first fixed by the 2 key polypropylene sutures attached to the mesh. Then, it is adjusted and fixed by absorbable staples on the periphery, without leaving any space for potential internal hernias between the prosthesis and the abdominal wall. A suction drain is inserted between the prosthesis and overlying abdominal wall in large hernias.

The laparoscopic port orifices are closed by polyglycolic acid 0 sutures.

\section{Stage III}

It is performed by the plastic surgeon. The operating room table is flexed at 10 to 15 degrees and the upper skin flap is pulled down to verify that it reaches the lower skin incision line.

Then the abdominal skin flap is fixed to the lower incision line. The novel skin opening for the umbilicus is marked and created (at about 2 $\mathrm{cm}$ above the bi-iliaque line). The panniculus to be resected is also marked on both sides. The flap is detached from the incision line to allow access to the umbilicus again and the umbilicus is fixed to the muscle aponeurosis by four $2 / 0$ resorbable sutures at 12, 6, 3 and 9 o'clock. Then the skin edges of the new umbilicus orifice are sutured to the muscle aponeurosis by 3 resorbable 2/0 sutures (12, 3 and 9 o'clock) of high tension. The panniculus is resected on both sides while beveling the cut inward at a 45-degree angle. To minimize tension and to close the undermined areas several polyglycolic acid 0 sutures are made between the fascia superficialis of the flap and the muscle aponeurosis. The incision is closed over 2 suction drains $3 / 0$ and $2 / 0$ sutures. A Vaseline dressing is placed in the umbilicus and a compressive dressing is fixed at the end of surgery.

The first dressing is performed on day 1 to verify the vascularisation of the umbilicus. Low-molecular heparin are introduced for 2 weeks. No antibiotics are used except if indicated. Only intra-operative antibiotic prophylaxis is used.

\section{RESULTS}

This retrospective series comprises the first 10 cases of this combined approach. They were only women at an average age of 35 years (range 29 to 44 years). All of them had rectus muscle diastasis associated with umbilical hernia. The diagnosis was made on the basis of the physical and ultrasound 
examination. All patients had postoperative compression abdominal gain for 2 months. The average follow-up period was 2.4 years (from 1 to 4 years). Post-operative visits were on days 14,30 , months 3 , 6 and 1 year. There were no complications related to the laparoscopic surgery. The average hospital stay was 2.8 days (from 2 to 5 days).
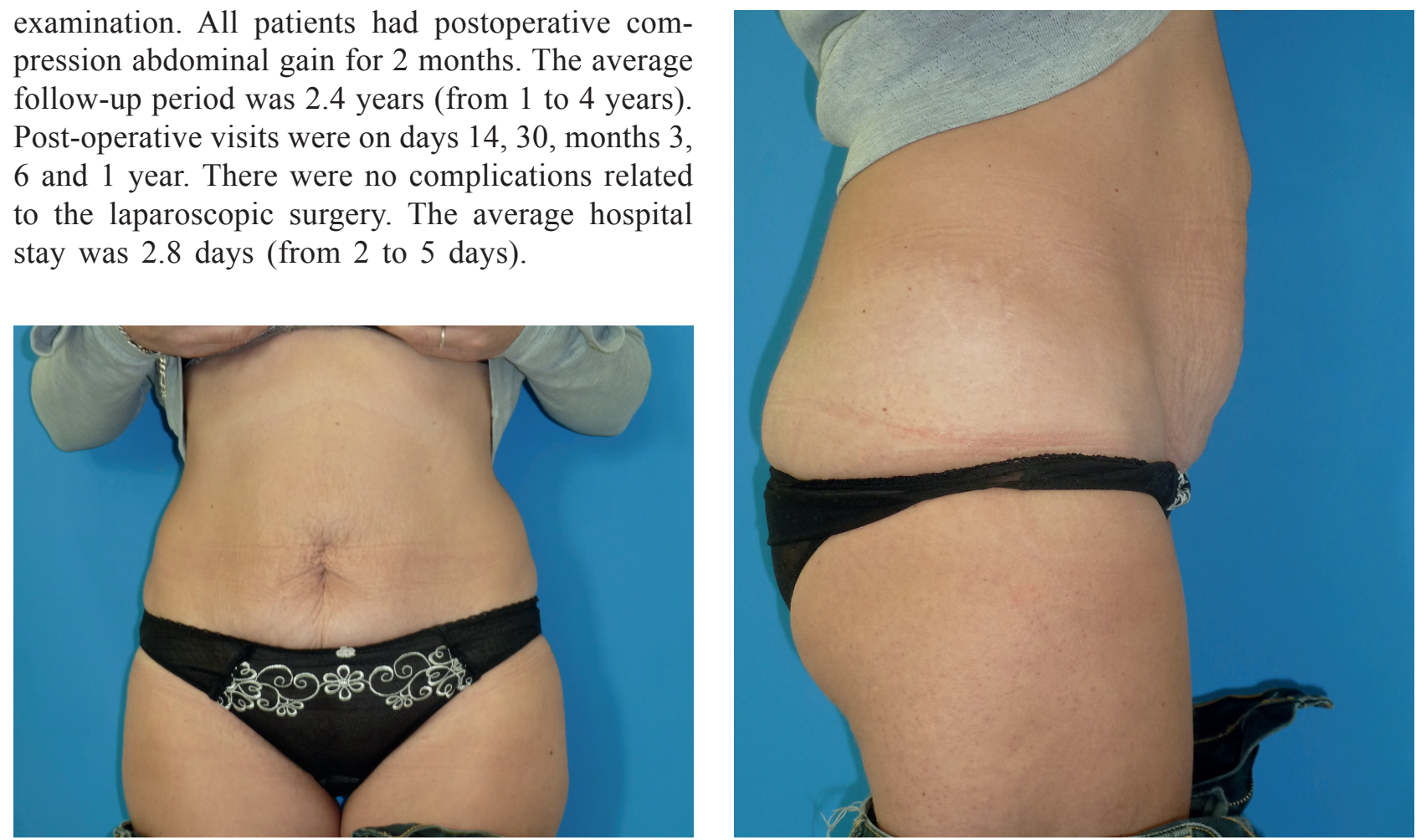

Figure 1 A.

Figure 1 B.
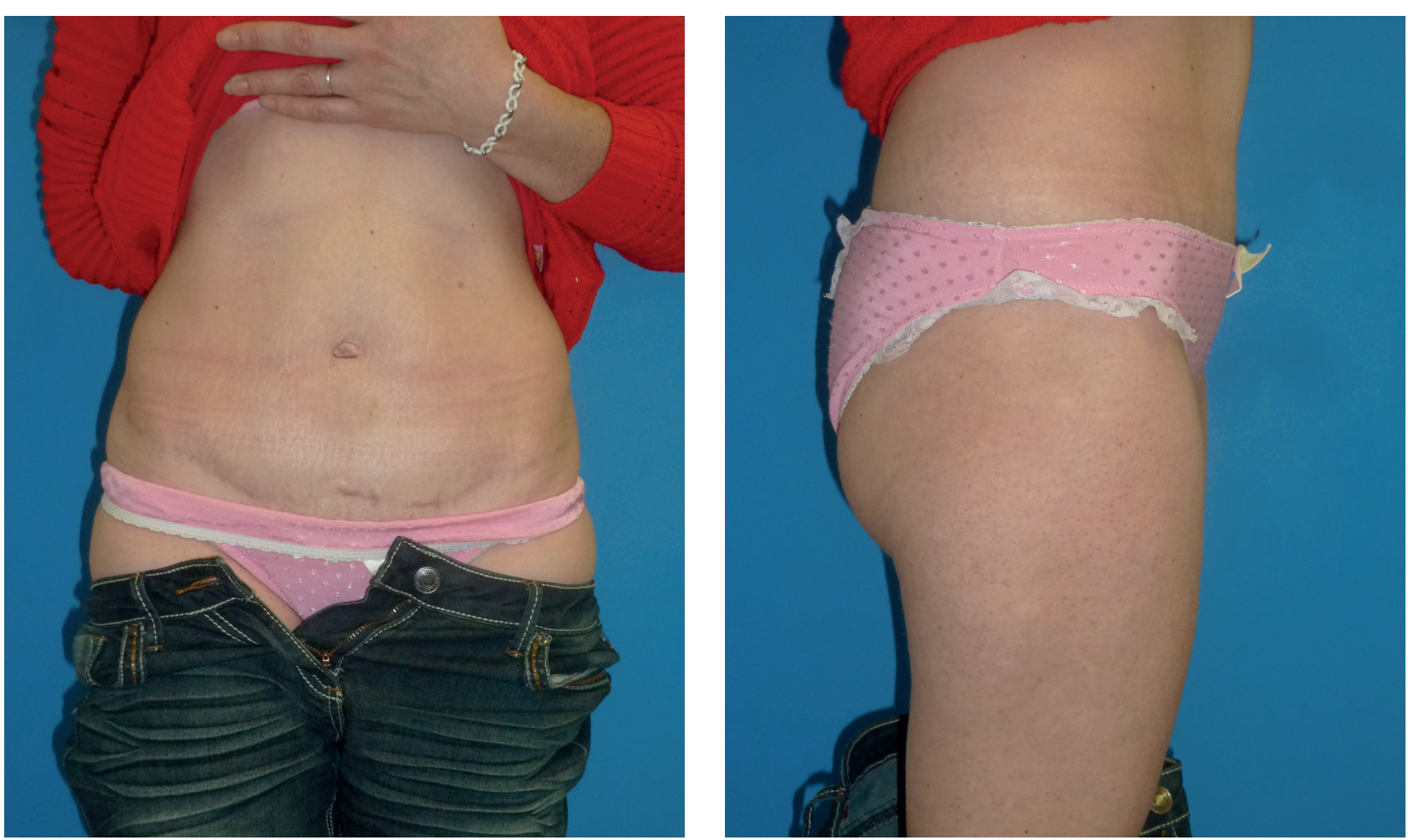

Figure $1 \mathrm{C}$.

Figure 1 D.

Figure 1. A 40 year-old patient who had simultaneous abdominoplasty and diastasis plus umbilical hernia repair. (A) and (B) - pre-operative face and right profile views. (C) and (D) - post-operative face and right profile views at one year. Note the correction of the skin surplus and the abdominal wall laxity as well as the improved form of the umbilicus. 


\section{DISCUSSION}

Combining UH repair with abdominoplasty can potentially lead to vascular compromise of the umbilical stalk. ${ }^{4}$ Since most of the candidates for abdominoplasty are young women the preservation of the umbilicus is of utmost importance. To increase the safety of this technique several approaches have been proposed for simultaneous abdominoplasty and UH hernia repair. In all available studies in the literature, the authors reported making direct repair of UH with or without mesh. McKnight et al. reported on the "right lateral" approach. ${ }^{4}$ They preserve the rectus muscle sheet completely on one side, placing the prosthesis between the rectus muscle and the posterior sheet on one side and the posterior sheet and the fascia transversalis on the other (to preserve the blood supply). A similar approach was reported by Bruner et al. but via a inferior midline incision in 17 patients without umbilical necrosis. ${ }^{5}$ Neinstein et al. used a Ventralex patch via open approach in 11 patients without vascular compromise. ${ }^{6}$ Bai et al. used open approach and polypropylene mesh in 10 patients but no information is reported about the vascularisation of the umbilicus. ${ }^{7}$ Kulhanek and Mestak performed the UH repair via open approach but the umbilicus stayed attached to the skin. ${ }^{8}$ In all cases the UH defect was approached via open approach $^{4-7}$ but not all studies reported on the post-operative vascularization of the umbilicus. We have also used the open approach with mesh repair in abdominoplasty but the outcomes were not always favorable.

We perform simultaneous abdominoplasty with or without RA diastasis with laparoscopic UH repair. The advantage is that the risk for umbilical ischemia is minimised. In our preliminary series of 10 patients we had no umbilical complications, neither had we any complications related to the prosthesis. No recurrences were observed. This preliminary data suggests that this approach is safe and can be proposed as another option for simultaneous abdominoplasty and umbilical hernia repair.

The operative time is reported longer in laparoscopic repairs. ${ }^{9}$ However, the open approach of $\mathrm{UH}$ repair in association of abdominoplasty requires incision of the aponeurosis of the rectus abdominis and the linea alba away from the umbilical stalk to minimize the vascular compromise to the umbilicus. ${ }^{4}$ In this case the positioning of the prosthesis is more time-consuming and the lengthening the procedure compared with simple UH repair. In this sense, the difference in operative time becomes insignificant having in mind that the risk of the umbilical vascularization is minimized. This is especially true if we take into consideration that decreased total and wound morbidity was reported with laparoscopic UH repair. ${ }^{9}$ In our series, all patients were young and without comorbidities and we did not have any respiratory or cardiac complications. The safety of the laparoscopic approach was also confirmed in recent studies. ${ }^{10,11}$

Another disadvantage of the procedure is that laparoscopy is an invasive intra-abdominal procedure. However, this is the case in any UH repair whether open or laparoscopic or robotic approach is preferred and whether direct closure or mesh repair is used. ${ }^{12}$ Another option would be the techniques of minimal scar incision as proposed by Kurpiewski W et al. but the latter is not adapted in our approach since it requires incision at the base of the umbilical stalk. ${ }^{13}$

That is why we have opted for a technique of UH repair that minimizes the vascular risk for the umbilicus virtually to the level of a simple abdominoplasty without hernia repair. The risk of necrosis and subsequent infection is decreased, which is especially important in cases of prosthesis repair where any umbilical infection is a potential risk to the mesh.

Finally, the reported approach seems to be consistent with the recently reported studies where abdominoplasty and minimally invasive surgery are in close relation. ${ }^{14}$

\section{CONCLUSION}

Our first results suggest that simultaneous abdominoplasty and UH repair via laparoscopy is feasible when indicated, minimizing the risk of umbilicus ischemia virtually to the level of simple abdominoplasty. These first results encourage us to recommend this approach and perform a more detailed analysis of the whole series since the first case.

\section{ACKNOWLEDGEMENTS}

We would like to thank the surgeons from the Department of General Surgery and Transplantation surgery of Croix Rousse Hospital for their collaboration since they have carried out the laparoscopic repairs of our abdominoplasty patients. In alphabetic order we would like to thank Dr Blehaut, Dr Demian, Pr Ducerf (Head of the Department), Dr Lanne, and Dr Mabrut. 


\section{REFERENCES}

1. Earle DB, McLellan JA. Repair of umbilical and epigastric hernias. Surg Clin North Am 2013;93:1057-89.

2. Strosberg DS, Pittman M, Mikami D. Umbilical hernias: the cost of waiting. Surg Endosc 2017;31(2):901-906.

3. Al-Qattan MM. Abdominoplasty in multiparous women with severe musculoaponeurotic laxity. Br J Plast Surg 1997;50:450-5.

4. McKnight CL, Fowler JL, Cobb WS, et al. Concomitant sublay mesh repair of umbilical hernia and abdominoplasty. Concomitant sublay mesh repair of umbilical hernia and abdominoplasty. Can J Plast Surg 2012;20(4):258-60.

5. Bruner TW, Salazer-Reyes H, Friedman JD. Umbilical hernia repair in conjunction with abdominoplasty: a surgical technique to maintain umbilical blood supply. Aesthetic Surg J 2009;29:333-4.

6. Neinstein RM, Matarasso A, Abramson DL. Concomitant abdominoplasty and umbilical hernia repair using the Ventralex hernia patch. Plast Reconstr Surg 2015;135(4):1021-5.

7. Bai M, Dai MH, Huang JZ, et al. Umbilical hernia repair in conjunction with abdominoplasty. Zhonghua Zheng Xing Wai Ke Za Zhi 2012 28(5):349-51.

8. Kulhanek J, Mestak O. Treatment of umbilical hernia and recti muscles diastasis without a periumbilical incision. Hernia 2013;17:527-30.

9. Cassie S, Okrainec A, Saleh F, et al. Laparoscopic versus open elective repair of primary umbilical hernias: short-term outcomes from the American College of Surgeons National Surgery Quality Improvement Program. Surg Endosc 2014;28:741-6.

10. Chen YJ, Huynh D, Nguyen S, et al. Outcomes of robot-assisted versus laparoscopic repair of smallsized ventral hernias. Surg Endosc 2016;31(3), 1275-9.

11. Malik AM. Laparoscopic versus open repair of para-umbilical hernia. Is it a good alternative? J Pak Med Assoc 2015;65:865-8.

12. Lau H, Patil NG. Umbilical hernia in adults. Surg Endosc 2003;17:2016-20.

13. Kurpiewski W, Kilianczyk M, Szynkarczuk R, et al. Mesh repair of umbilical hernia without a visible abdominal scar. Pol Przegl Chir 2014;86:68-72.

14. Janis JE, Khansa I. Evidence-based abdominal wall reconstruction: the maxi-mini approach. Plast Reconstr Surg 2015;136(6):1312-23.

\title{
Одновременная абдоминопластика и восстановление пупочной грыжи с применением лапароскопии: предварительный доклад
}

\author{
Христо Д. Шипков ${ }^{1,2}$, Али Моджаллал ${ }^{1}$, Фабиен Бре ${ }^{1}$ \\ ${ }^{1}$ Кафедра пластической, реконструктивной и эстетической хирургии, Больница красного креста, Лион, Франция \\ 2 Клиника пластической и черепно-лицевой хирургии, Университетская больница "Св. Георгий" - Пловдив, Болгария
}

\author{
Адрес для корреспонденции: \\ Христо Д. Шипков, \\ Кафедра пластической, \\ реконструктивной и \\ эстетической хирургии, \\ Больница красного крест, 103 \\ Grande rue de la Croix Rousse, \\ Лион, Франция \\ E-mail: cshipkov@hotmail.com \\ тел: 0033426732822
}

Дата получения: 05 октября 2015

Дата приемки: 16 ноября 2016 Дата онлайн публикации: 06 марта 2017

Дата публикации: 27 июня 2017

Ключевые слова: абдоминопластика, пупочная грыжа, лапароскопское восстановление
Введение: Пупочные грыжи (ПГ) являются распространёнными у пациентов в послеродовый период, которые проявляют интерес к операции по коррекции живота и в связи с этим поднимается вопрос об одновременной абдоминопластике и восстановлении ПГ. Но это чревато риском для пупочной васкуляризации с вероятным пупочным некрозом. Для уменьшения риска нами было предусмотрено совместное проведение абдоминопластики и лапароскопского восстановления ПГ.

Цель: Целью исследования является представление техники одновременной абдоминопластики и восстановления ПГ и первоначальных результатов.

Методы: Одновременная абдоминопластика и восстановление ПГ с применением сетки были анализированы в первых 10 случаях. Интервенцию осуществили пластический и общий хирурги. Она началась как стандартная абдоминопластика с поднятием абдоминального лоскута, отделением пупка и востановления диастаза, при наличии индикаций. Второй этап включал восстановление ПГ с применением лапароскопии с интраперитонеальной пластикой сеткой. Третий этап состоял из пупочной транспозиции и закрытия надреза абдоминопластики. 


\section{Образец цитирования:}

Shipkov HD, Mojallal A, Braye F. Simultaneous abdominoplasty and umbilical hernia repair via laparoscopy : a preliminary report. Folia Medica 2017;59(2):222-227. doi: 10.1515/folmed-2017-0026
Результаты: Не было проявления усложнений с пупком или грыжевой сеткой. Во всех случаях пупочная васкуляризация осталась незатронутой и не наблюдалось рецидива грыжи.

Заключение: Первоначальные результаты показывают, что одновременное восстановление ПГ с применением абдоминопластики является безопасным, понижающим риск кровоснабжения пупка. Данные первоначальные результаты дают нам основание рекомендовать данный подход и осуществить более детальный анализ всей серии первых случаев. 